\title{
When places change their names on maps. Cases study from the Arab world
}

\author{
Mohsen Dhieb ${ }^{\mathrm{a}}$ \\ ${ }^{a}$ Laboratory SYFACTE-GEOMAGE - University of Sfax - Tunisia (in temporary assignment with KAUniversity, Jeddah, Saudi \\ Arabia) and ATCIG. mohsendhieb2003@yahoo.fr
}

\begin{abstract}
The transcription of geographical names on maps in one given language is a very complex process. Depending on the used language, toponyms are mostly deformed from their natural language. In the Arab world, this deformation is treated in various ways. In many cases, Arabic place names suffer a double distortion when first transcribed from Arabic or another original language into French or English, and second when taking the same way back. Through a review of examples from some Arab place names, a few cases are analyzed to reveal the mechanisms of such anomaly and a strategy is recommended to avoid it.

Departing from Arabic atlases, we will realize three steps. First, we examine this anomaly through case studies taken from the English and French toponymic transcriptions. Second, the produced names area compared to those of other countries, considering the processes and mechanisms involved. Third, we propose a global strategy to overcome this anomaly in transcribing names in the Arab world by prioritizing produced transformations.

The proposed strategy witnesses the concept of standardized "exendonyms" presented and discussed in a previous research for foreign languages such as French or English. When Arabic is used, the phonetic local transcription is recommended but should also fit transcription rules of the used language as much as possible. In doing so, transcripts should not shift or deviate so far from original name places and much ambiguity can be avoided. This strategy must obey standardized international rules and may repose on modern techniques or media.
\end{abstract}

Keywords: Arab World, Place names, Toponymic transcription

\section{Introduction}

Reading place names on maps and understanding their signification and their links to geographical features and references is an essential task for the map users. The way and the context names are attributed to one territory, region, country or any smaller area or feature reveal often their geographical identity, historical construction and linguistic development. "As we stated in a precedent research, over the world, toponyms "are living bodies that observe various evolutions towards time" (Dhieb, 2015). This apply all over the world of course and particularly in countries having witnessed various civilizations and multiple linguistic events and evolutions. Various factors intervene to determine real toponymic transcriptions and various explanations are given to it whether considering the local or the international uses. Some of them are very clear and understandable whereas some others are unclear and require special attention and profound examination.

When the native language is used, the transcript is believed to obey the rules of it. In reality, sometimes, the place names are derived from the deformed exonyms written in a foreign language. In this case, the transcript is deformed twice and the result can sometimes be intriguing and the place name indecipherable to the native reader and probably to the foreign reader, especially if he is aware of the real transcript. The extreme case is when the endonyms are written as exonyms in their own countries using their proper languages.
Moreover, when a foreign language is used, the toponym may have bizarre forms of transcription to the point it may not be recognized by native speakers.

This is particularly true in the Arab world where the linguistic legacy is the result of quite diverse historical and civilizational events despite a seemingly solid base of common Arabic language. In fact, the linguistic landscape of the Arab world is much more diversified from one country to another and from one region to another, and even inside a single country and within a single region, as it can be seen from a few case studies.

We shall therefore recommend a rational and pragmatic strategy for the transcription of toponymy, avoiding unfortunate deformations, and considering both the hasty reproduced and almost trivialized habits, causing ambiguity, perplexity and misunderstanding, as well as systematic decisions of "Latinization" of place names, under the guise of creating exonyms. This strategy is supposed to bring the toponym closer to its use.

\section{The Arab world toponymy: an overview of the toponymical situation}

Arabic is one of the first languages spoken in the world. Geographically, the Arab countries which form the Arab World are in the heart of the Old World and share two continents, Africa and Asia and are just separated from Europe by the Mediterranean Sea. Today, Arabic is the 
official language of the countries composing this entity. With more than 300 million of Arabic speakers all over the

world $(4.23 \%)$, it ranks at the fifth rank in the world, but it represents certainly more if we consider that Arabic is spoken also in large portions of African Sahelian countries whereas some regions such as the Kurdistan in Irak and Syria or some Berber regions in North Africa are using Berber or Kurdish. In other words, many language maps based on official spoken languages are misleading: the linguistic true maps not must be based only on political boundaries but also on real situations (Figures 1, 2 and 3 ).

Arabic is characterized by its diglossia between colloquial and Modern Standard Language, mostly derived from Classical Arabic, more or less close to spoken and written forms throughout the Arab countries. It is descending from a mix of ancient languages mostly disappeared and is spoken today in the two different geographical entities forming the Arab World: North Africa and the Middle East in various ways. Now Arabic is growing rapidly and its two forms are diverging greatly.

Overall, the current toponymic situation of the Arab world is characterized by its extreme complexity, due to both its historical legacy and its recent history, but also to the particular geopolitical and linguistic situations, bilingual or trilingual but rarely unilingual (Arabic but also French or English). Yet these languages are used besides local ancient languages such as Berber or Kurdish and other local dialects and various regional dialects. Therefore, establishing standardized transcriptions of Arab toponyms whether in Arabic or French, with the least amount of mistakes, turns out to be a hazardous and risky operation a priori although it has constituted the main goal of some researches (Dhieb 2008, 2013, 2015; Zagorsky, 2010, 2012).

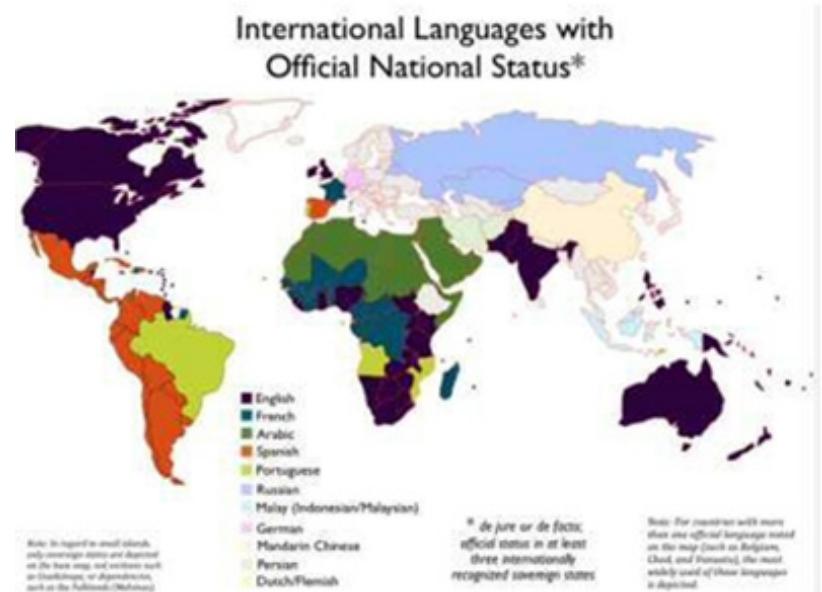

http://www.geocurrents.info/category/place/world/page/3

Fig. 1. A country-based map showing the current distribution of human language families in the world.

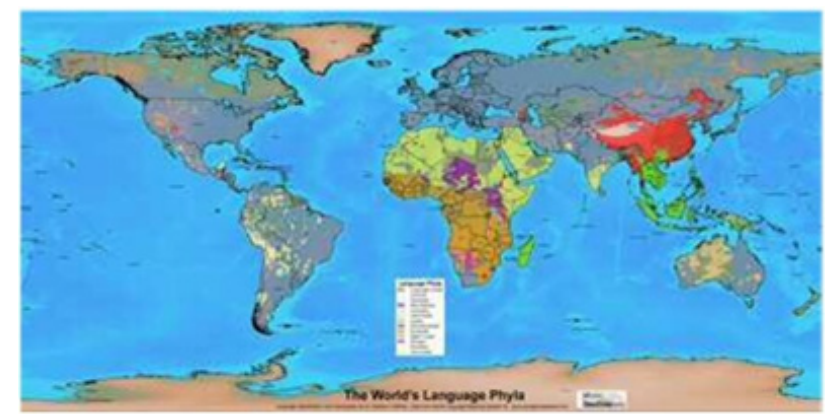

http://www.worldgeodatasets.com/language/huffman/\#zoomIma ge7601

Figure 2. World map showing the real distribution of languages not considering country borders.

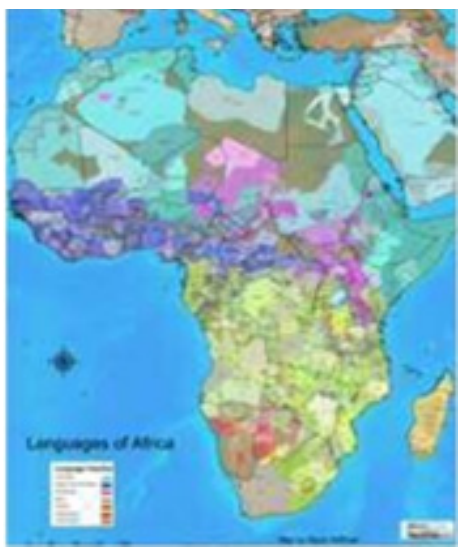

http://www.worldgeodatasets.com/language/huffman/\#zoomIma ge7601

Figure 3. Languages of Africa map showing the real distribution of the Arabic language in North Africa and the Middle-East.

This complexity is reflected on the ways place names are written on maps using Arabic, French or English. As we stated in a precedent research, "The way and the context the geographical names are attributed to one territory, region, country or any smaller area or feature reveal often their geographical identity, historical construction and linguistic development" (Dhieb and al., 2012).

\subsection{Map toponymy of the Arab world: main characteristics}

Maps of the Arab world, contain various name transcriptions whether in Arabic or other languages. Obviously, place names on maps do not obey a regular and

clear strategy of transcription and when this happen, it is rarely presented, commented or explained by map authors. Moreover, due to historical different trajectories of the eastern part (Middle-East) and the western part (North Africa) of the Arab World, the toponyms vary greatly from one document to another one on maps. For instance, one can find up to 5 and probably more of different transcriptions of the capital of Egypt: Quahira, Al Qahira, El Qahira, Le Caire, Caire for the French versions only.

Linguistic deformation is found in several other cases and documents whether atlases, map books and other cartographic and geographic products containing 
geographical names written in Arabic or in foreign languages. Several of these place names are transcribed in so curious way that they happen to be preposterous. This is because they suffer a double distortion when first transcribed from the original language to the new language, often from Arabic into French or English, and second taking the same way back, passing again from Latin languages into Arabic. Through a review of examples from some Arabic atlases, a few cases are proposed to illustrate this anomaly. We will try to reveal the mechanisms of such anomaly and recommend a strategy to avoid such deviations.

There are a few controversial linguistic toponyms as it happens for the Arab

Gulf, written also as Persian Gulf already discussed, or geopolitical conflicts and disputes such as for the Sahara Occidental (الصحر اء الغربية), Rio de Oro (أورو ريو دي), or As Seguia Al Hamra (الساقية الحمراء) when it is not purely integrated within Morocco. But besides these extreme cases, more common place names change often their transcriptions.

In Arabic, two cases do happen:

- The first one is implied by direct Arabic transcription originated from the spoken Arabic. In general, this transcription obeys the local pronunciation and is understood and easily recognized by common Arab readers.

- The second one is more complex: sometimes, names on Arabic maps are translated from foreign languages as most of map works especially when elaborated are produced in foreign countries. Depending on the principles of transcribing exonyms, in other words, how far and different is the exonym from the endonym, and depending on how geographical names are derived and interpreted, the transcription may be very misleading.

Because Alep is the exonym of the city of the endonym Halab, its Arabic transcription retrieved in some atlases is (بل). In Tunisia, (ترزيب) is the transcription of the exonym Bizerte, which is in reality spoken Benzarte or (ترنس); (ترس);

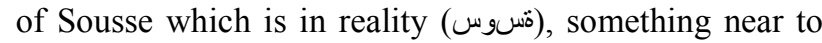
Soussa; Kairouan which is in reality locally pronounced El Quirwène in colloquial and $\mathrm{Al}$ Quayrawèn in Classical Arabic. One of the most famous examples is probably given by the city of Zaghwèn (ناوغز) which has been translated in French on the first topographic French sheets as Zarhwèn because of the difficulties to pronounce the letter $(\dot{\xi})$ is transformed into rh which in turns is transformed into $\left(\rho^{\circ}\right)$; so in finql the original Berber toponym of (ناوغز) becomes (ناوهرز) , that is probably another imaginary city.

These are only a few cases of many. We limited our analysis here intentionally to some spectacular cases, keeping in mind that studying all Arabic names towards this issue can be an overwhelming task. But we must also include to this situation other controversial cases due to Arabic map authors who retain for Arabic the way they learn or read the Arab toponyms transcribed in French, English, Spanish or other languages. This reproduction is due to authors efforts and inspiration and does not repose to standardized rules admitted by the scientific community and workable.

These are only a few cases of many. We limited our analysis here intentionally to some spectacular cases, keeping in mind that studying all Arabic names towards

this issue can be an overwhelming task. But we must also include to this situation other controversial cases due to Arabic map authors who retain for Arabic the way they learn or read the Arab toponyms transcribed in French, English, Spanish or other languages. This reproduction is due to authors efforts and inspiration and does not repose to standardized rules admitted by the scientific community and workable.

\subsection{Case analysis}

It is overwhelming to review all the Arab names posing transcription problems, we will just cite some striking examples departing from an overview of some geographical atlases, and will analyze some cases illustrating these anomalies. First, these latter are examined through case studies of names taken from English or French versions of toponymic transcription. Second, we will also try to classify the geographical names of the Arab world and those related to other countries of the world taking into account the fact that in both cases, the processes and mechanisms involved are only in these two cases are not similar. The proposed strategy to overcome this anomaly transcription of names of geographical places in the Arab world consider two criteria: phonetic transcription and linguistic rules of the foreign language used.

For instance, if we consider some of the most cases, $\mathrm{Al}$ Maghrib means literally the country of the West in Arabic as it is located at the very end of the Arab World is preferred to the French exonym Maroc and to the English one Morocco. The other case is Misr, the local place name is preferred too to Egypte and to Egypt. The toponymic aspects of biggest rivers of Arab countries are dressed in the following table 1:

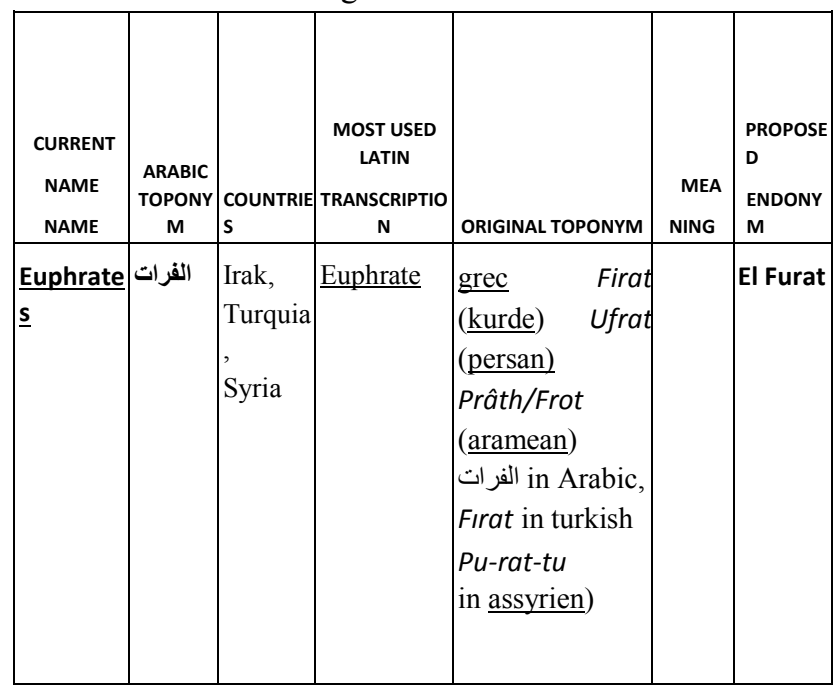




\begin{tabular}{|c|c|c|c|c|c|c|c|c|c|c|c|c|c|c|}
\hline \multirow[t]{2}{*}{$\begin{array}{l}\text { Oum Er- } \\
\text { rabiâ }\end{array}$} & \multirow[t]{2}{*}{ المولوية } & \multirow{2}{*}{$\mid \begin{array}{l}\text { Morbêa } \\
\text { Oum } \\
\text { Rebiaa }\end{array}$} & & \multirow[t]{2}{*}{$\begin{array}{l}\text { Wansifen } \\
\text { (Berber) }\end{array}$} & \multirow{2}{*}{$\begin{array}{l}\text { Many } \\
\text { source } \\
\text { s }\end{array}$} & \multirow{2}{*}{$\begin{array}{l}\text { Oum } \\
\text { Ar- } \\
\text { rabiaa }\end{array}$} & Sectornym & Escargots & Babbouch & Babbouche & Bebbouch & \multirow{2}{*}{$\begin{array}{l}\text { Babbouch } \\
\text { Beni Mtir }\end{array}$} & \multirow{2}{*}{\begin{tabular}{|l} 
Babbouch \\
Bni Mtir
\end{tabular}} & \multirow{2}{*}{\begin{tabular}{|l|}
$\begin{array}{l}\text { Babbo } \\
\text { u } \\
\text { che }\end{array}$ \\
Bni \\
Mtir
\end{tabular}} \\
\hline & & & & & & & $\begin{array}{l}\text { Sectornym } \\
\text { Communy } \\
\mathrm{m}\end{array}$ & $\begin{array}{l}\text { Descendan } \\
\text { ts of } \\
\text { Mtir }\end{array}$ & Beni Mtir & Beni M'tir & Bani Mtir & & & \\
\hline \multirow[t]{2}{*}{$\begin{array}{l}\text { Moulouy } \\
\text { a }\end{array}$} & & & & & & \multirow[t]{2}{*}{$\left|\begin{array}{ll}\text { Al } & M \\
\text { louya }\end{array}\right|$} & Sectornym & $\begin{array}{l}\text { source of } \\
\text { Hamraya }\end{array}$ & $\begin{array}{l}\text { Ain } \\
\text { Elhamraya }\end{array}$ & $\begin{array}{lr}\text { Ain } \\
\text { Hamraya }\end{array}$ & \begin{tabular}{|l} 
Ain \\
Hamraya
\end{tabular} & $\begin{array}{l}\text { Ain } \\
\text { Elhamraya }\end{array}$ & $\begin{array}{ll}\text { Ain } & \text { E } \\
\text { hamraya } & \end{array}$ & $\begin{array}{l}\text { Ain El } \\
\text { Hamra } \\
y \\
\text { a }\end{array}$ \\
\hline & & & & & & & Sectornym & \begin{tabular}{|l} 
Tribe \\
name; \\
oronym
\end{tabular} & Khemir & El Khemir & & Khemir & Khmir & Khmir \\
\hline $\begin{array}{l}\text { Medjerd } \\
\text { a, }\end{array}$ & مجرده & Tunisia & $\begin{array}{l}\text { Medjerdah } \\
\text { ou Majerda }\end{array}$ & Bagrada & & $\begin{array}{l}\text { Mejerd } \\
\text { a }\end{array}$ & \multirow[b]{2}{*}{ Sectornym } & \multirow{2}{*}{$\begin{array}{l}\text { Bourguiba } \\
\text { bath }\end{array}$} & \multirow{2}{*}{$\begin{array}{l}\text { Hammam } \\
\text { Bourguiba }\end{array}$} & \multirow{2}{*}{$\begin{array}{l}\text { Hammem } \\
\text { Bourguiba }\end{array}$} & & \multirow{2}{*}{$\begin{array}{l}\text { Hammam } \\
\text { Bourguiba }\end{array}$} & \multirow{2}{*}{$\begin{array}{l}\text { Hammem } \\
\text { Bourguiba }\end{array}$} & \multirow{2}{*}{$\begin{array}{l}\text { Hamm } \\
\text { e m } \\
\text { Bourgu } \\
\text { i ba }\end{array}$} \\
\hline \multirow[t]{4}{*}{ Nile } & \multirow[t]{4}{*}{ النيل } & \multirow[t]{4}{*}{ Egypt } & \multirow[t]{4}{*}{ Nil } & \multirow{4}{*}{$\begin{array}{l}\text { grec } \\
\text { (Neilos) } \\
\text { Ancient } \\
\text { Egyptien ( } \mathrm{Na} \text { - } \\
\text { eior, } \\
\text { of eior (delta) }\end{array}$} & & \multirow[t]{4}{*}{ An Nil } & & & & & & & & \\
\hline & & & & & & & $\begin{array}{l}\text { Delegony } \\
\mathrm{m}, \\
\text { Communy } \\
\mathrm{m}\end{array}$ & $\begin{array}{l}\text { Berber } \\
\text { origin } \\
\text { name }\end{array}$ & Tabarga & Tabarba & Tabarca & Tabarka & Tbarka & Tbarka \\
\hline & & & & & & & Sectornym & & Sidi Rouine & Sidi Rouin & & $\begin{array}{l}\text { Sidi } \\
\text { Rouine }\end{array}$ & Sidi Rouine & \begin{tabular}{|l} 
Sidi \\
Rouine
\end{tabular} \\
\hline & & & & & & & Sectornym & & Al Kabir & El Kébir & Kbir & El Kébir & El Kbir & El Kbir \\
\hline \multicolumn{7}{|c|}{ Table 1. Toponymic list of the biggest Arab rivers } & Sectornym & $\begin{array}{l}\text { The cut } \\
\text { off or }\end{array}$ & Al Gassa & El Guessa & Guessa & Guessa & El Guessa & \begin{tabular}{|l|} 
El \\
Guessa \\
\end{tabular} \\
\hline \multicolumn{7}{|c|}{$\begin{array}{l}\text { Whereas an extract of the Tunisian toponymic } \\
\text { Geodatabase is given as example in Table } 2 \text {, showing the } \\
\text { various }\end{array}$} & $\mid \begin{array}{l}\text { Sectornym } \\
\text { Regionym }\end{array}$ & & $\begin{array}{l}\text { Maknet Al } \\
\text { Hamaine }\end{array}$ & $\begin{array}{l}\text { Maknet El } \\
\text { Hemaine }\end{array}$ & $\begin{array}{l}\text { Maknet } \\
\text { Hemaine }\end{array}$ & $\begin{array}{l}\text { Maknet El } \\
\text { Hemaine }\end{array}$ & $\begin{array}{l}\text { Maknet El } \\
\text { Hmaine }\end{array}$ & $\begin{array}{l}\text { Makne } \\
\mathrm{t} \\
\text { El } \\
\text { Hemai } \\
\text { n } \\
\text { e }\end{array}$ \\
\hline
\end{tabular}

\begin{tabular}{|c|c|c|c|c|c|c|c|c|}
\hline $\begin{array}{l}\text { ANCIEN } \\
\text { T NAME }\end{array}$ & $\begin{array}{c}\text { TOPONY } \\
\mathrm{M}\end{array}$ & $\begin{array}{l}\text { MEANIN } \\
\text { G OF } \\
\text { TOPONY } \\
\text { M OR } \\
\text { ORIGIN } \\
\end{array}$ & \begin{tabular}{|c|} 
MOST \\
USED \\
TRANSCRIP \\
TI ON \\
\end{tabular} & $\begin{array}{c}\text { OTHER } \\
\text { TRANSCRIP } \\
\text { TI } \\
\text { ON } 1\end{array}$ & \begin{tabular}{|cc|}
\multicolumn{2}{|c|}{ OTHER } \\
TRANSCRIP \\
TI & \\
& ON \\
& 2 \\
\end{tabular} & $\begin{array}{l}\text { PRESENT } \\
\text { EXONYM }\end{array}$ & $\begin{array}{l}\text { ENDONY } \\
\text { M }\end{array}$ & \begin{tabular}{|l|} 
PROPO \\
SED \\
EXEND \\
ONYM
\end{tabular} \\
\hline \multirow[t]{2}{*}{$\begin{array}{l}\text { Souk } \\
\text { Larbaa }\end{array}$} & \begin{tabular}{|l|} 
Governym \\
Delegony \\
$\mathrm{m}$, \\
Communy \\
$\mathrm{m}$
\end{tabular} & $\begin{array}{l}\text { Tribe of } \\
\text { Jendoubi }\end{array}$ & Jendouba & Jandouba & & Jendouba & Jandouba & $\begin{array}{l}\text { Jendou } \\
\text { ba }\end{array}$ \\
\hline & Sectornym & Happiness & Al Saada & Saada & El Saada & Essaada & Essaada & $\begin{array}{l}\text { Essaad } \\
\text { a }\end{array}$ \\
\hline \multirow[t]{3}{*}{$\begin{array}{l}\text { Souk } \\
\text { El } \\
\text { Khemis }\end{array}$} & \begin{tabular}{|l} 
Delegony \\
$\mathrm{m}$, \\
Communy \\
$\mathrm{m}$
\end{tabular} & & Bou Salem & Bou salem & Bousalem & Bousalem & Bou sèlem & $\begin{array}{l}\text { Bou } \\
\text { Sèlem }\end{array}$ \\
\hline & Sectornym & & Al Azima & El Azima & & Azima & El Azima & $\begin{array}{l}\text { El } \\
\text { Azima }\end{array}$ \\
\hline & Sectornym & $\begin{array}{l}\text { Tribe of } \\
\text { Mnasri }\end{array}$ & Al Mnasria & El Mnsaria & Mnasria & Mnassria & El Mnsaria & $\begin{array}{l}\text { El } \\
\text { Mnsari } \\
a\end{array}$ \\
\hline & $\begin{array}{l}\text { Delegony } \\
\mathrm{m}, \\
\text { Communy } \\
\mathrm{m}\end{array}$ & $\mid \begin{array}{ll}\text { Gare } & \text { de } \\
\text { Mao } & \text { or } \\
\text { Blood } & \\
\text { grotto } & \end{array}$ & $\begin{array}{l}\text { Ghardimao } \\
\mathrm{u}\end{array}$ & Ghardima & $\begin{array}{l}\text { Ghar Ad } \\
\text { Dima }\end{array}$ & $\begin{array}{l}\text { Ghardimao } \\
\mathrm{u}\end{array}$ & Ghardima & $\begin{array}{l}\text { Ghardi } \\
\text { ma }\end{array}$ \\
\hline & Sectornym & $\begin{array}{l}\text { Female } \\
\text { name }\end{array}$ & Halima & Hlima & Sidi Hlima & Hlima & Hlima & Hlima \\
\hline & Localnym & $\begin{array}{l}\text { Romain } \\
\text { name }\end{array}$ & Thubumica & Tubumica & & $\begin{array}{l}\text { Thubumic } \\
\text { a }\end{array}$ & Thubumica & $\begin{array}{l}\text { Thubu } \\
\text { mica }\end{array}$ \\
\hline & Sectornym & & El Ouchtata & Ouachtata & Ouechtata & Ouchtata & Ouechtata & \begin{tabular}{|l|} 
Ouecht \\
a \\
ta
\end{tabular} \\
\hline & Sectornym & $\begin{array}{l}\text { Romain } \\
\text { name }\end{array}$ & Chamtou & Chemtou & Chimtu & Chemtou & Chemtou & $\begin{array}{l}\text { Chemt } \\
\text { o } \\
\text { u }\end{array}$ \\
\hline & Sectornym & & Fedja & Feija & Al Feîja & El Feyja & El Feyja & El Feyja \\
\hline & Sectornym & $\begin{array}{l}\text { source of } \\
\text { money }\end{array}$ & $\begin{array}{l}\text { Ain } \\
\text { Drahem }\end{array}$ & Ain Draham & Aîn Drahem & $\begin{array}{l}\text { Ain } \\
\text { Drahem }\end{array}$ & $\begin{array}{l}\text { Aîn } \\
\text { Drahem }\end{array}$ & $\begin{array}{l}\text { Aïn } \\
\text { Drahe } \\
\mathrm{m}\end{array}$ \\
\hline
\end{tabular}

Table 2: An extract of the Tunisian toponymic Geodatabase established (Dhieb M., 2013).

\section{Conclusions, strategy and recommandations}

In a precedent research, Dhieb stated "Transcribing toponymic features on maps is an essential task for the map authors when lacking an official source, whatever the language used." (Dhieb, 2015). For Arabic, we can say that only minor problems arise when we start from Arabic names sources documents. For other language versions, origins such as Berber or Kurd, we must transcribe spelling

as in a similar way when doing so with foreign languages. "For the map user, reading the names transcript on maps by using the rules of one language does not help a lot to understanding the richness and the variety of local toponymy. The various historical, cultural and geopolitical aspects are very often occulted.

For foreign transcriptions, our proposed strategy witnesses the concept of exendonyms, presented and discussed in a previous search (Dhieb, M. 2013) which repose on getting as closer as possible endonyms to exonyms, instead and in place of exonyms traditionally used to transcribe foreign names that build a sensitive distance from names and reality. In such a way, transcripts should not shift or deviate so far from original name places and ambiguity can be avoided.

This strategy must be obeying standardized strict rules that may help in the context of globalization. In such manner, we will see maps transcribing "Halab" rather than the French exonym Alep or the English one "Aleppo"! based ratherly with respect to local 
pronunciation as well as to foreign languages rules, as much as possible.

\section{References}

Ben Jaafar E., (1985). Les noms de lieux en Tunisie. Tunis, Editions du CERES.

Fawaz Baker, ' Questions de toponymie Ş, Égypte/Monde arabe, PremiËre sČrie, 5 1991, mis enligne le 08 juillet 2008, consultČ le 16 fČvrier 2017. URL: http://ema.revues.org/900

Dhieb M., (2008). Toponymes Tunisiens : vers une normalisation de la transcription. Oral communication in 31st IGC, IGU, Tunis, August 2008.

Dhieb M. and Saada A. (2011). Toponymes de la TUNISIA dans la cartographie occidentale du XVIIIËme SIECLE. Oral communication, 25th ICC, Paris.

Dhieb M. (2012). ElČments d'analyse et de comprČhension de la toponymie Tunisienne : cas du golfe de GuËbis. Oral communication in IGC of Koln, Germany.

Dhieb M. (2012). Cartographie et toponymie. Quand l'habit ne fait point Le moine ! In Cahiers du CERES, série « Cartographie » N. 1, Tunis, pp 135-151.

Dhieb M. (2013). Towards a geographical database of names in Tunisia: The case of the map sheet of Sfax NW \# 1071. Toponyms in Cartography, Proceedings of the Toponymic Sessions at the 25th International Cartographic Conference, Paris, 3-8 July 2011. Peter Jordan and Peter Ormeling (Eds.). Verlag Dr. Kovac. pp. 19-30. 